\title{
Erratum to low-dose spectral CT perfusion imaging of lung cancer quantitative analysis in different pathological subtypes
}

\author{
Editorial Office \\ Translational Cancer Research \\ Correspondence to: Editorial Office. Translational Cancer Research. Email: tcr@amepc.org.
}

Submitted Jan 26, 2022. Accepted for publication Jan 28, 2022.

doi: $10.21037 /$ tcr-22-203

View this article at: https://dx.doi.org/10.21037/tcr-22-203

Erratum to: Transl Cancer Res 2021;10:2841-8

In the article that appeared on Page: 2841-2848, Vol 10, No 6, (June 2021) Issue of the Translational Cancer Research (TCR) (1), there was an omission of co-first authorship. Mai-Lin Chen and Yi-Yuan Wei were both first authors. This article was corrected online.

Click here to view the updated version of the article.

Open Access Statement: This is an Open Access article distributed in accordance with the Creative Commons AttributionNonCommercial-NoDerivs 4.0 International License (CC BY-NC-ND 4.0), which permits the non-commercial replication and distribution of the article with the strict proviso that no changes or edits are made and the original work is properly cited (including links to both the formal publication through the relevant DOI and the license). See: https://creativecommons.org/ licenses/by-nc-nd/4.0/.

\section{References}

1. Chen ML, Wei YY, Li XT, et al. Low-dose spectral CT perfusion imaging of lung cancer quantitative analysis in different pathological subtypes. Transl Cancer Res 2021;10:2841-48.

Cite this article as: Editorial Office. Erratum to low-dose spectral CT perfusion imaging of lung cancer quantitative analysis in different pathological subtypes. Transl Cancer Res 2022;11(2):435. doi: 10.21037/tcr-22-203 